\title{
Characterization of metabolic differences between embryogenic and non-embryogenic cells in forest trees
}

So-Young Park, Wi-Young Lee, Yong-Wook Kim, Heung-Kyu Moon

From IUFRO Tree Biotechnology Conference 2011: From Genomes to Integration and Delivery Arraial d'Ajuda, Bahia, Brazil. 26 June - 2 July 2011

Somatic embryogenesis (SE) in forest trees is considered as one powerful approach in cloning elite genotypes. However, SE is difficult to achieve in tissue or cell beyond the mature embryo phase in trees and its physiological process involved are also poorly understood. Recently metabolic profiling studies have been contributed to understand the mechanism involved in SE process of plant [1-3]. In addition, there are also a
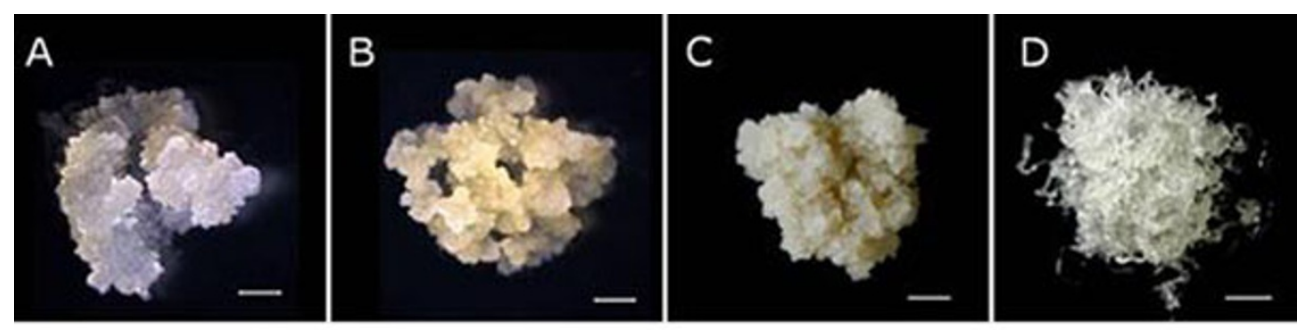

Brood loavod treo: Yollow poplar
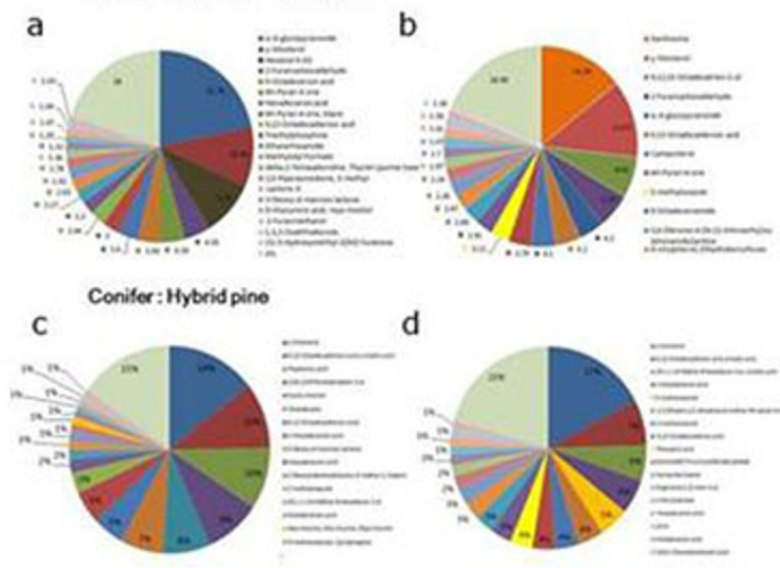

d

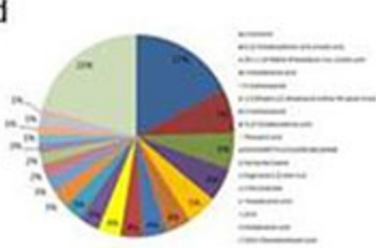

Figure 1 Non-embryogenic (NEC; $A, C$ ) and embryogenic cells (EC; B, D) of yellow poplar and hybrid pine 'rigida $x$ taeda' respectively, and its metabolic compositions (NEC: $a, c$ and EC: $b, d$ ).

\footnotetext{
* Correspondence: soypark7@korea.kr Korea Forest Research Institute

(c) 2011 Park et al; licensee BioMed Central Ltd. This is an open access article distributed under the terms of the Creative Commons Bïomed Central Attribution License (http./creativecommons.org/licenses/by/200), which permits unrestricted use, distribution, and reproduction in any medium, provided the original work is properly cited.
} 
number of reports indicating that polyamines (PAs) play a crucial role in SE process $[4,5]$. As part of an ongoing study of the transition of somatic cells to an embryogenic state in adult trees, embryogenic (EC) and nonembryogenic cells (NEC) in various forest species were investigated for its metabolic compositions including PAs. A comparison of metabolic compositions of NEC and EC using gas chromatography/mass spectrometry (GC/MS) identified around 50 compounds, partly displaying significant changes in metabolite levels, e.g., highly elevated levels of xanthosine and methyloxazole in EC compared to NEC of broadleaves and conifer species (Fig.1). Changes in the polyamine content were also analyzed in both cell types. Free polyamine contents varied according to the species and cell types, the highest levels occurring in the NEC on proliferation medium, when putrescine and spermidine were most abundant. However, the putrescine/spermine+spermidine (put/spm +spd) ratio was higher in EC of yellow poplar and hybrid pine. Analysis of PAs in both cell types indicated that total polyamine concentration was always higher in NEC than in EC, and spermine was present in only minute quantities and showed only a small change. From this analysis, we have identified numerous compounds involved with embryogenic state, and could characterize its differences between broadleaves and conifer trees.

Published: 13 September 2011

\section{References}

1. Dowlatabadi R, Weljie AM, Thorpe TA, Yeung EC, Vogel HJ: Metabolic footprinting study of white spruce somatic embryogenesis using NMR spectroscopy. Plant physiol biochem 2009, 47:343-350.

2. Hosp J, Tashpulatov A, Roessner U, Barsova E, Katholnigg H, Steinborn R, Melikant B, Lukyanov S, Heberle-Bors E, Touraev A: Transcriptional and metabolic profiles of stress-induced, embryogenic tobacco microspores. Plant Mol Biol 2007, 63:137-149.

3. Robinson AR, Dauwe R, Ukrainetz NK, Cullis IF, White R, Mansfield SD: Predicting the regenerative capacity of conifer somatic embryogenic cultures by metabolomics. Plant Biotech I 2009, 7:952-963.

4. Minocha SC, Minocha R: Role of polyamines in somatic embryogenesis. In Biotechnology in Agriculture and Forestry. Volume 30. Heidelberg: SpringerVerlag;Bajaj YPS 1995:55-72.

5. Mala J, Cvikrova M, Machova P, Martincova O: Polyamines during somatic embryo development in Norway spruce (Picea abies [L.]). J For Sci 2009, 55:75-80.

doi:10.1186/1753-6561-5-S7-P146

Cite this article as: Park et al:: Characterization of metabolic differences between embryogenic and non-embryogenic cells in forest trees. BMC Proceedings 2011 5(Suppl 7):P146.

\section{Submit your next manuscript to BioMed Central} and take full advantage of:

- Convenient online submission

- Thorough peer review

- No space constraints or color figure charges

- Immediate publication on acceptance

- Inclusion in PubMed, CAS, Scopus and Google Scholar

- Research which is freely available for redistribution

Submit your manuscript at www.biomedcentral.com/submit
C Biomed Central 